\title{
Teachers' Opinions Regarding the Usage of Action Research in Professional Development
}

\author{
Celal Yigit ${ }^{1}$, Birsen Bagceci ${ }^{1}$ \\ ${ }^{1}$ University of Gaziantep, Turkey \\ Correspondence: Celal Yigit, University of Gaziantep, Turkey.
}

Received: September 14, 2016

Accepted: December 29, 2016

Online Published: January 23, 2017

doi:10.11114/jets.v5i2.1878

URL: http://dx.doi.org/10.11114/jets.v5i2.1878

\begin{abstract}
The aim of the study is to investigate the contribution of action research to teachers' professional development. In line with this goal, a group of teachers were asked their opinions. The working group of the study is comprised of six teachers working at a state primary and middle school. The study is an example of "Case Study", one of qualitative research methods. The content analysis technique was utilized in the analysis of the data. To sum up, the teachers expressed that action research had a positive impact on their professional development in various aspects.
\end{abstract}

Keywords: action research, professional development, case study

\section{Introduction}

\subsection{Problem}

Humanbeings have been in a quest of quality within their limits ranging from industry to education. Then, what is quality? Lexically, it is defined as "embodying the best-known qualities of a product" (TDK, 2015), "a quality that somebody or something possesses" (Merriam-Webster, 2015), "(in industry) lacking faults, mistakes and significant variations" (Business Dictionary, 2015) and "the degree to what extent internal characteristics satisfy needs" (Word Press, 2015).

Teachers have a vital role in helping people improve their skills, actualize their potential and acquire complicated information and skills that they need as citizens or employees. Teachers are those mediating between the swiftly-changing world and students about to enter it. Teaching profession is getting more and more sophisticated and demands expected from teachers are going up. Within the scope of the Bologna process, among the teaching competences and qualifications are "a high-quality profession", "a profession of people learning lifelong", "a mobile profession" and "a profession based on cooperation" (CEC, 2007).

Teachers' professional development is a significant factor in ensuring the effectiveness of reforms at any levels. Successful professional development opportunities for teachers have a positive bearing on students' performance and learning. Thus, teachers' professional should be regarded as a key factor if the aim is to enhance students' learning and performances (Villegas-Reimers, 2003).

The most outstanding teacher training approach is to combine scientific knowledge and theory from practice and train teachers as researchers (Ekiz, 2006). It is quite apparent that teachers' professional development is essential to make education more fruitful. Yet, it is stated that most of the professional development programs directed at teachers result in failure. Action Research, based on solving problems through research by teachers' following a certain process for a specific problem, stands as an alternative with regard to offering a solution to teachers' professional development. Action Research is of great significance as it enables teachers to solve their problems on their own to a great extent

Teachers focus on their practices and handle their problems directly in Action Research. Teachers themselves are also influenced by the changes and improvements they make. It is seen that participants involved in an action research consider themselves as more effective teachers and have a more positive attitude towards their profession (Atay, 2003; as cited in Kuzu, 2009).

Involved in a classroom or school-based action research, teachers can focus on their professional development primarily and divert their professional development to which direction they want. It can be adapted to the needs of the trainer(s) or the trainer team. Some specific fields needing improvement could be the focus of personalized or customized 
professional development. Teachers regard such professional development as more meaningful as they have an opportunity to improve the areas they choose (Mertler, 2013).

Whether carried out as individually or as a team work, teacher research enables teachers to be involved in designing and implementing researches serving as productive professional development experiences. Teacher research is influential as it activates teachers, provides opportunities to be cooperative, handle real world problems and their own problems (Cochran-Smith and Lytle, 1993; as cited in. Kim, 2008)

Action Research is a practical way of going over one's work to check whether it is in the desired way. It is mostly considered as practitioner-based research as it includes thinking and reflecting about one's work. Furthermore, it could be regarded as a kind of self-reflective practice (Ferguson, 2011).

A number of action research cycles could be found in the literature. Two new ones were created by Yigit (2016) as a result of literature survey and then action research workshops and practices (as it is said to be flexible in the literature) and one of these action research cycles could be seen in Figure 1 below:

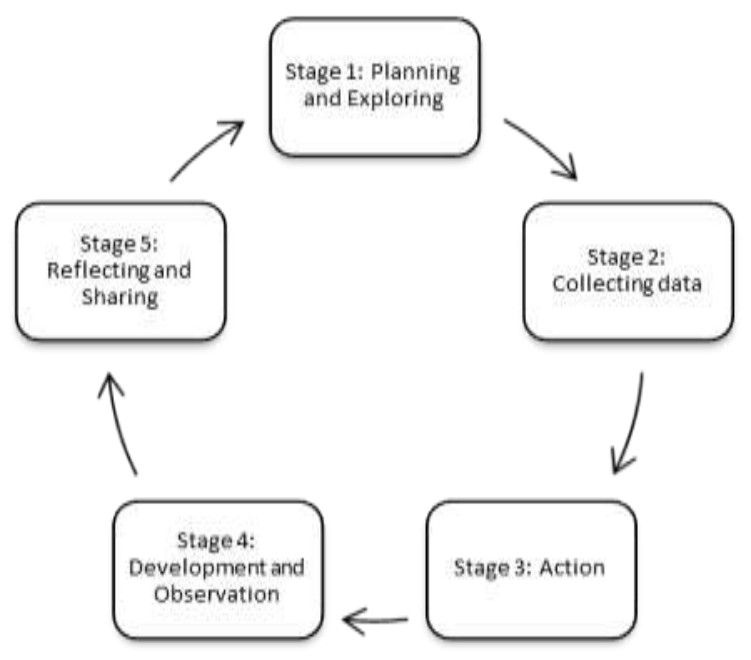

Figure 1. Action Research Cycle (Yigit, 2016)

Steps are briefly explained below:

Stage 1: Several tools are employed to specify the problem, set the goal and find necessary tools to active it.

Stage 2: Literature is surveyed and data are collected with respect to the problem.

Stage 3: Action is initiated after using several tools to solve the problem and drawing an action research proposal/plan.

Stage 4: Action plan is revised after missing points are determined and observation is made again regarding the problem.

Stage 5: Teachers reflect about the results of the action researches and inform their colleagues and/or sharholders (Yigit, 2016).

\subsection{Explore Importance of the Problem}

Most of the professional developments fail (Guskey, 2002). Courses or workshops serve different goals, whereas drawing a program, discussing evaluation data or sharing strategies serve some other goals (Avalos, 2011). Professional development activities which are short, temporary or split from practice have little influence. On the other hand, well-designed professional development may remediate the teaching practice and students' achievement (Wei, Darling-Hammond and Adamson, 2010).

\section{Method}

\subsection{Identify Subsections}

The research is of a qualitative design. The research as to Action Research in teachers' professional development is an example of Case Study, an approach facilitating the usage of the discovery of a phenomenon in its own context using data triangulation. What's common between Yin and Stake, using different methods in their case studies, is that the topic of interest is discovered well and the essence of the issue is uncovered (Baxter and Jack, 2008).

The working group of the study is comprised of six state school teachers who underwent an Action Research training. It 
involved warm-up and ice-breaker activities, problem specification methods and techniques, literature survey, data collection, organization, analysis, reporting and effective presentation techniques.

The teacher-researchers were encouraged and supported to carry out their action researches in line with the definition of Ferguson (2011) and the action research cycle drawn by Yigit (2016). Some of the research topics handled by the teachers were "the impact of homework on students' achievement", "how to teach students effectively by overcoming difficulties", "problems regarding the material usage in Turkish lessons", "classroom management", etc. To illustrate, the teacher addressing "homework" had a literature survey and collected data from her class using observation reports, homework check lists and self and peer-assessment techniques. She reported improvement in the quality of her students' assignments. Then, the teacher who studied how to teach effectively made use of creative problem specification and solving techniques and interviewed her colleagues. She analyzed the data and reported the findings. Having found out the reasons for ineffective teaching, she made some changes. She met some other teachers and parents as well. She concluded that there were fewer distraction but she still had some problems. She also decided to get more help from the Guidance and Counselling Service.

The data were collected using a semi-structured interview form including question about their usage of Action Research. The responses to the interview were gathered using Google docs, e-mail, written report, etc. just to make the teachers feel comfortable to express their opinions.

\subsection{Data Analysis}

Firstly, teachers were coded as Teacher 1 to 6 . Content analysis was utilized in the analysis of the data. The main goal of content analysis is to reach concepts and relations for which data are conceptualized. Afterwards, the data are re-organized and themes are determined. Thus, phenomena could be organized or understood better (Yildirim \& Simsek, 2006).

According to Yin (1984), in order to make a research design more effective, its internal and external validity and reliability should be ensured. The objectivity is under risk as subject judgements could interfere in the process (as cited in Yildirim and Simsek, 2006). In the study, two experts in the field were consulted for the content analysis conducted and thus categorization and themes were confirmed.

\section{Results}

Table 1. Effect of Action Research on Professional Development in terms of "Knowledge of Field"

\begin{tabular}{|c|c|c|c|c|c|}
\hline Teacher 1 & Teacher 2 & Teacher 3 & $\begin{array}{l}\text { Teacher } 4 \\
\end{array}$ & Teacher 5 & Teacher 6 \\
\hline $\begin{array}{l}\text { Cooperation } \\
\text { "It enabled us to share } \\
\text { with each other } \\
\text { professionally." } \\
\text { "We started to develop } \\
\text { a common plan." } \\
\text { Alternative Ways of } \\
\text { Solution } \\
\text { "We noticed that there } \\
\text { is more than one } \\
\text { solution to the } \\
\text { problems and we } \\
\text { could reach these by } \\
\text { improving ourselves } \\
\text { continuously." } \\
\text { Communication } \\
\text { "It enhanced } \\
\text { communication } \\
\text { [among teachers]." } \\
\text { "It enabled us to feel } \\
\text { emphaty with the } \\
\text { students seeing their } \\
\text { context } \\
\text { searching for the } \\
\text { reasons for the } \\
\text { problems in the class." }\end{array}$ & $\begin{array}{l}\text { Alternative Ways of } \\
\text { Solution } \\
\text { "Upon finding out the } \\
\text { reasons for the } \\
\text { problems in the class, } \\
\text { I tried to look for } \\
\text { alternative ways of } \\
\text { solution. For this } \\
\text { reason, I got help } \\
\text { from the people } \\
\text { aroud me (teachers, } \\
\text { friends)." }\end{array}$ & & $\begin{array}{l}\text { Self-Criticism } \\
\text { "Action research has } \\
\text { enabled me to } \\
\text { criticize myself by } \\
\text { helping me see my } \\
\text { weaknesses in my } \\
\text { own field." } \\
\text { Gainining } \\
\text { Awareness } \\
\text { "I noticed once } \\
\text { more that I need to } \\
\text { improve myself } \\
\text { because of my field } \\
\text { (information } \\
\text { technologies)." }\end{array}$ & $\begin{array}{l}\text { Opportunity to Find } \\
\text { Solutions } \\
\text { "Thanks to the } \\
\text { brainstorming } \\
\text { activities, it taught us } \\
\text { how to behave and } \\
\text { get results and which } \\
\text { stages to track." }\end{array}$ & $\begin{array}{l}\text { Gainining } \\
\text { Awareness } \\
\text { "It helped me be } \\
\text { informed about to } \\
\text { what extent I make } \\
\text { use of materials in } \\
\text { my lessons and how } \\
\text { to concretize the } \\
\text { Turkish lesson which } \\
\text { is abstract." } \\
\text { Opportunity to Find } \\
\text { Solutions } \\
\text { "It canalized me to } \\
\text { look for ways of } \\
\text { solutions to make use } \\
\text { of materials in the } \\
\text { lessons." }\end{array}$ \\
\hline
\end{tabular}

The results regarding the first sub-dimension named "Knowledge of Field" are provided in Table 1 below:

As seen in Table 1, all the opinions regarding "Knowledge of Field" are positive from the point of view of Action Research. The opinions could be listed under the main themes "professional development, solutions and communications". The teachers expressed that they had positive sharing among them, made plans and criticized 
themselves noticing their weaknesses thanks to Action Research. It is understood that their level of awareness in different aspects such as teaching methodologies increased and it is stated that professional development should be continuous. Moreover, it is also striking that Action Research offers solutions to problems. Then, it is seen that teachers started looking for alternative ways of solutions. Finally, teachers express that their communication with the students improved.

The results regarding the second sub-dimension named "Pedagogy" are provided in Table 2 below.

As shown in Table 2, all the opinions concerning "Pedagogy" are also all positive. The opinions could be gathered under the themes "updating knowledge, learners' developmental characteristics, gaining awareness, teaching methods and techniques and opportunity to find solutions". The point focused more here is that teachers gain more information about learners' developmental characteristics thanks to Action Research. Next, it is seen that they gain an opportunity to review their teaching methodologies. Thirdly, as mentioned in "Field of Knowledge", Action Research contributes to teachers in terms of gaining awareness about finding solutions to classroom problems and developing solutions".

Table 2. Effect of Action Research on Professional Development in terms of "Pedagogy"

\begin{tabular}{|c|c|c|c|c|c|}
\hline Teacher 1 & Teacher 2 & Teacher 3 & Teacher 4 & Teacher 5 & Teacher 6 \\
\hline $\begin{array}{l}\text { Update of } \\
\text { Knowledge } \\
\text { "As all the training } \\
\text { contributed to us } \\
\text { positively in terms } \\
\text { of process-based } \\
\text { and scientific } \\
\text { thinking, it has } \\
\text { provided us with } \\
\text { new and up-to-date } \\
\text { information" } \\
\text { Learners' } \\
\text { Developmental } \\
\text { Characteristics } \\
\text { "It has given us } \\
\text { clues about } \\
\text { educational } \\
\text { activities directed } \\
\text { at learners' } \\
\text { developmental } \\
\text { characteristics } \\
\text { together with close } \\
\text { follow-up these } \\
\text { characteristics." }\end{array}$ & $\begin{array}{l}\text { Gaining Awareness } \\
\text { "I saw that the } \\
\text { problems in the } \\
\text { classroom } \\
\text { decreased } \\
\text { students' } \\
\text { motivation. These } \\
\text { problems had to be } \\
\text { minimized to } \\
\text { increase their } \\
\text { motivation. } \\
\text { Therefore, I have } \\
\text { thought about how } \\
\text { to have my lessons } \\
\text { in a fun and more } \\
\text { active way." } \\
\text { Teaching Methods } \\
\text { and Techniques } \\
\text { "We have had our } \\
\text { lessons in a fun } \\
\text { way, creating } \\
\text { games in line with } \\
\text { the topics with the } \\
\text { students." }\end{array}$ & $\begin{array}{l}\text { Teaching Methods } \\
\text { and Techniques } \\
\text { "Thanks } \\
\text { reviewing to } \\
\text { literature, I got } \\
\text { more informed } \\
\text { about teaching } \\
\text { methods and } \\
\text { techniques." }\end{array}$ & $\begin{array}{l}\text { Learners' } \\
\text { developmental } \\
\text { characteristics } \\
\text { "While searching } \\
\text { about how I can be } \\
\text { more helpful for } \\
\text { my students, I } \\
\text { learned more about } \\
\text { their age group } \\
\text { characteristics." } \\
\text { Teaching Methods } \\
\text { and Techniques } \\
\text { "... I had a } \\
\text { chance to review } \\
\text { the materials that I } \\
\text { can use in my } \\
\text { lessons." }\end{array}$ & $\begin{array}{l}\text { Opportunity to } \\
\text { Find Solutions } \\
\text { "It taught me how } \\
\text { to evaluate a } \\
\text { problem from } \\
\text { different angles } \\
\text { and how to } \\
\text { emphatize." }\end{array}$ & $\begin{array}{l}\text { Learners' } \\
\text { developmental } \\
\text { characteristics } \\
\text { "... it has becme } \\
\text { useful in terms of } \\
\text { getting individuals' } \\
\text { characteristics into } \\
\text { account." } \\
\text { Opportunity to } \\
\text { Find Solutions } \\
\text { "It was useful for } \\
\text { identifying } \\
\text { problems regarding } \\
\text { education and their } \\
\text { reasons and finding } \\
\text { solutions." }\end{array}$ \\
\hline
\end{tabular}

As seen in Table 3, all the opinions of the teachers regarding "Gaining Knowledge Regarding Learners" are positive from the point of view of Action Research. The opinions could be gathered under the themes "positive impact upon learners, Gaining Knowledge, Lessons in a More Fun Way, gaining awareness and techniques and opportunity to find solutions". The point focused most is that it had a positive impact upon learners. Then, they report that it had a positive impact on themselves as well as the learners. Having lessons in a more fun way and opportunity to find solutions, as mentioned in "Field of Knowledge" and "Pedagogy", are two other benefits of Action Research for the teachers. As stated in the previous two sub-dimensions, it is seen that there is an increase in the awareness level of the students. Finally, it seems that the teachers appropriated the Action Research training.

The results regarding the second sub-dimension named "Gaining Knowledge Regarding Learners" are provided in Table 3 below: 
Table 3. Effect of Action Research on Professional Development in terms of "Gaining Knowledge Regarding Learners"

\begin{tabular}{|c|c|c|c|c|c|}
\hline Teacher 1 & Teacher 2 & Teacher 3 & Teacher 4 & Teacher 5 & Teacher 6 \\
\hline $\begin{array}{l}\text { Positive Impact } \\
\text { upon Learners } \\
\text { "Teachers made a } \\
\text { program in line } \\
\text { with the "action } \\
\text { research plan" } \\
\text { based on the } \\
\text { training they got, } \\
\text { which could be } \\
\text { said to have } \\
\text { provided positive } \\
\text { feedback the } \\
\text { learners" } \\
\text { "The learners were } \\
\text { involved in this } \\
\text { plan and they } \\
\text { appropriated the } \\
\text { change in the } \\
\text { classroom in a } \\
\text { positive and curios } \\
\text { way as the } \\
\text { activities were } \\
\text { different from } \\
\text { usual. } \\
\text { Gaining knowledge } \\
\text { "They [Students] } \\
\text { may be said to } \\
\text { have increased } \\
\text { their knowledge } \\
\text { thanks to their } \\
\text { original activities." } \\
\text { Appropriating } \\
\text { training } \\
\text { "They [Students] } \\
\text { may be said to } \\
\text { have appropriated } \\
\text { the training to their } \\
\text { original activities." }\end{array}$ & $\begin{array}{l}\text { Positive Impact } \\
\text { upon Learners } \\
\text { "It has had a } \\
\text { positive impact on } \\
\text { the students } \\
\text { interest in lessons." } \\
\text { "It had a positive } \\
\text { impact on some of } \\
\text { the students who } \\
\text { are not interested in } \\
\text { lessons." } \\
\text { Lessons in a more } \\
\text { fun way } \\
\text { "Games } \\
\text { appropriate for the } \\
\text { topics (contests - } \\
\text { puzzles) helped the } \\
\text { lesson become } \\
\text { more fun." }\end{array}$ & $\begin{array}{l}\text { Gaining Awareness } \\
\text { "As a result of the } \\
\text { deductions from } \\
\text { parent and teacher } \\
\text { interviews, I saw } \\
\text { how the students } \\
\text { acted in which } \\
\text { conditions and I } \\
\text { will be able to use } \\
\text { it for the problems } \\
\text { that may occur in } \\
\text { the future." }\end{array}$ & $\begin{array}{l}\text { Gaining knowledge } \\
\text { "I have got } \\
\text { informed more } \\
\text { about why students } \\
\text { perform certain } \\
\text { actions." } \\
\text { Gaining Awareness } \\
\text { "I have noticed my } \\
\text { mistakes about } \\
\text { students' mistakes } \\
\text { in the lessons as a } \\
\text { consequence of the } \\
\text { researches I have } \\
\text { carried out." }\end{array}$ & $\begin{array}{l}\text { Opportunity to } \\
\text { Find Solutions } \\
\text { "It has taught us } \\
\text { how to define a } \\
\text { problem, how to } \\
\text { find solutions and } \\
\text { how to act under } \\
\text { which } \\
\text { circumstances." }\end{array}$ & $\begin{array}{l}\text { Positive Impact } \\
\text { upon Learners } \\
\text { "It provided a more } \\
\text { concrete learning } \\
\text { setting for the } \\
\text { students and } \\
\text { facilitated } \\
\text { internalizing } \\
\text { concepts." }\end{array}$ \\
\hline
\end{tabular}

The results regarding the second sub-dimension named "Teaching Methodologies" are provided in Table 4 below:

Table 4. Effect of Action Research on Professional Development in terms of "Teaching Methodologies"

\begin{tabular}{|c|c|c|c|c|c|}
\hline Teacher 1 & Teacher 2 & Teacher 3 & Teacher 4 & Teacher 5 & Teacher 6 \\
\hline $\begin{array}{l}\text { Various } \\
\text { Solutions } \\
\text { "We tried to } \\
\text { contemplate } \\
\text { about how to } \\
\text { transfer the } \\
\text { teaching } \\
\text { methodologies } \\
\text { we learned } \\
\text { during this } \\
\text { training and } \\
\text { make use of } \\
\text { different } \\
\text { methods and } \\
\text { techniques." }\end{array}$ & $\begin{array}{l}\text { Active Learning } \\
\text { Environment } \\
\text { "Active } \\
\text { learning } \\
\text { environment } \\
\text { has been } \\
\text { ensured by } \\
\text { minimizing the } \\
\text { problems about } \\
\text { being } \\
\text { uninterested in } \\
\text { the lessons." }\end{array}$ & $\begin{array}{l}\text { Problem } \\
\text { Solving } \\
\text { "I noticed that } \\
\text { most problems } \\
\text { could be } \\
\text { handled if the } \\
\text { essence of the } \\
\text { problem is } \\
\text { uncovered using } \\
\text { the methods we } \\
\text { used to identify } \\
\text { problems. } \\
\text { Action } \\
\text { Research helped } \\
\text { me solve some } \\
\text { of the problems } \\
\text { in my class. I } \\
\text { will make use } \\
\text { of them when I } \\
\text { encounter } \\
\text { similar } \\
\text { problems in the } \\
\text { future." }\end{array}$ & $\begin{array}{l}\text { Review } \\
\text { "I reviewed the } \\
\text { teaching } \\
\text { methods I used } \\
\text { it to minimize } \\
\text { negative student } \\
\text { behaviours with } \\
\text { this research. I } \\
\text { researched more } \\
\text { effective } \\
\text { methods and put } \\
\text { them into } \\
\text { practice." }\end{array}$ & $\begin{array}{l}\text { Problem } \\
\text { Solving } \\
\text { "It taught me } \\
\text { that a problem } \\
\text { is not solved } \\
\text { suddenly but } \\
\text { gradually and } \\
\text { step by step." }\end{array}$ & $\begin{array}{l}\text { Active Learning } \\
\text { Environment } \\
\text { "It contributed } \\
\text { to learning by } \\
\text { doing, concrete } \\
\text { learning, active } \\
\text { learning and } \\
\text { individual-based } \\
\text { learning in } \\
\text { terms } \\
\text { teaching of } \\
\text { methodologies." }\end{array}$ \\
\hline
\end{tabular}


As seen in Table 4, all the opinions of the teachers regarding "Teaching Methodologies" are positive from the point of view of Action Research. The opinions could be gathered under the themes "different solutions, active learning environment, problem solving and review". The teachers expressed that a more active learning environment was ensured and their problem solving skills got better. Additionally, they drew attention to the studies about differentiation and variation of teaching methodologies and they had a chance to review them.

The results regarding the second sub-dimension named "Teaching Methodologies" are provided in Table 5 below:

Table 5. Effect of Action Research on Professional Development in terms of "Curriculum"

\begin{tabular}{|c|c|c|c|c|c|}
\hline Teacher 1 & Teacher 2 & Teacher 3 & Teacher 4 & Teacher 5 & Teacher 6 \\
\hline $\begin{array}{l}\text { Variety of } \\
\text { Activities } \\
\text { "We had various } \\
\text { activities where } \\
\text { possible in the } \\
\text { curriculum. For } \\
\text { instance, we } \\
\text { formed lesson } \\
\text { objectives } \\
\text { which could be } \\
\text { achieved } \\
\text { through various } \\
\text { activities } \\
\text { suitable for } \\
\text { basic learning } \\
\text { points } \\
\text { Turkish of } \\
\text { education in the } \\
\text { Turkish lesson." }\end{array}$ & & $\begin{array}{l}\text { Problem } \\
\text { Solving } \\
\text { "It enabled me } \\
\text { to solve the } \\
\text { problems in the } \\
\text { lesson and focus } \\
\text { on it better. It } \\
\text { helps students } \\
\text { understand } \\
\text { lessons better." }\end{array}$ & $\begin{array}{l}\text { Detailed } \\
\text { Review } \\
\text { "I had a chance } \\
\text { to go over the } \\
\text { Information } \\
\text { Technologies } \\
\text { curricula and } \\
\text { plans in a more } \\
\text { detailed way } \\
\text { and put them } \\
\text { into practice by } \\
\text { making them } \\
\text { flexible when } \\
\text { suitable." }\end{array}$ & $\begin{array}{l}\text { Problem } \\
\text { Solving } \\
\text { "What to do } \\
\text { when problems } \\
\text { occur is } \\
\text { researched and } \\
\text { reflected onto } \\
\text { the program." }\end{array}$ & $\begin{array}{l}\text { Preparation of } \\
\text { Course } \\
\text { Materials } \\
\text { "I paid attention } \\
\text { to the principles } \\
\text { of educational } \\
\text { materials such } \\
\text { as being } \\
\text { economic, } \\
\text { flexible, } \\
\text { approporiate } \\
\text { and clear and } \\
\text { these principles } \\
\text { were adhered } \\
\text { while preparing } \\
\text { materials." }\end{array}$ \\
\hline
\end{tabular}

As seen in Table 5, all the opinions of the teachers regarding "Curriculum" are positive from the point of view of Action Research. The opinions could be gathered under the themes "variety of activities, problem solving, detailed review and preparation of course materials". As stressed in the previous sub-dimensions, teachers point out the importance of Action Research in terms of problem solving. Also, the teachers state that they had a variation in their activities, a detailed review of the curricula and developed new course materials in line with the course material preparation principles.

The results regarding the second sub-dimension named "General Pedagogical Knowledge" are provided in Table 6 below:

Table 6. Effect of Action Research on Professional Development in terms of "General Pedagogical Knowledge"

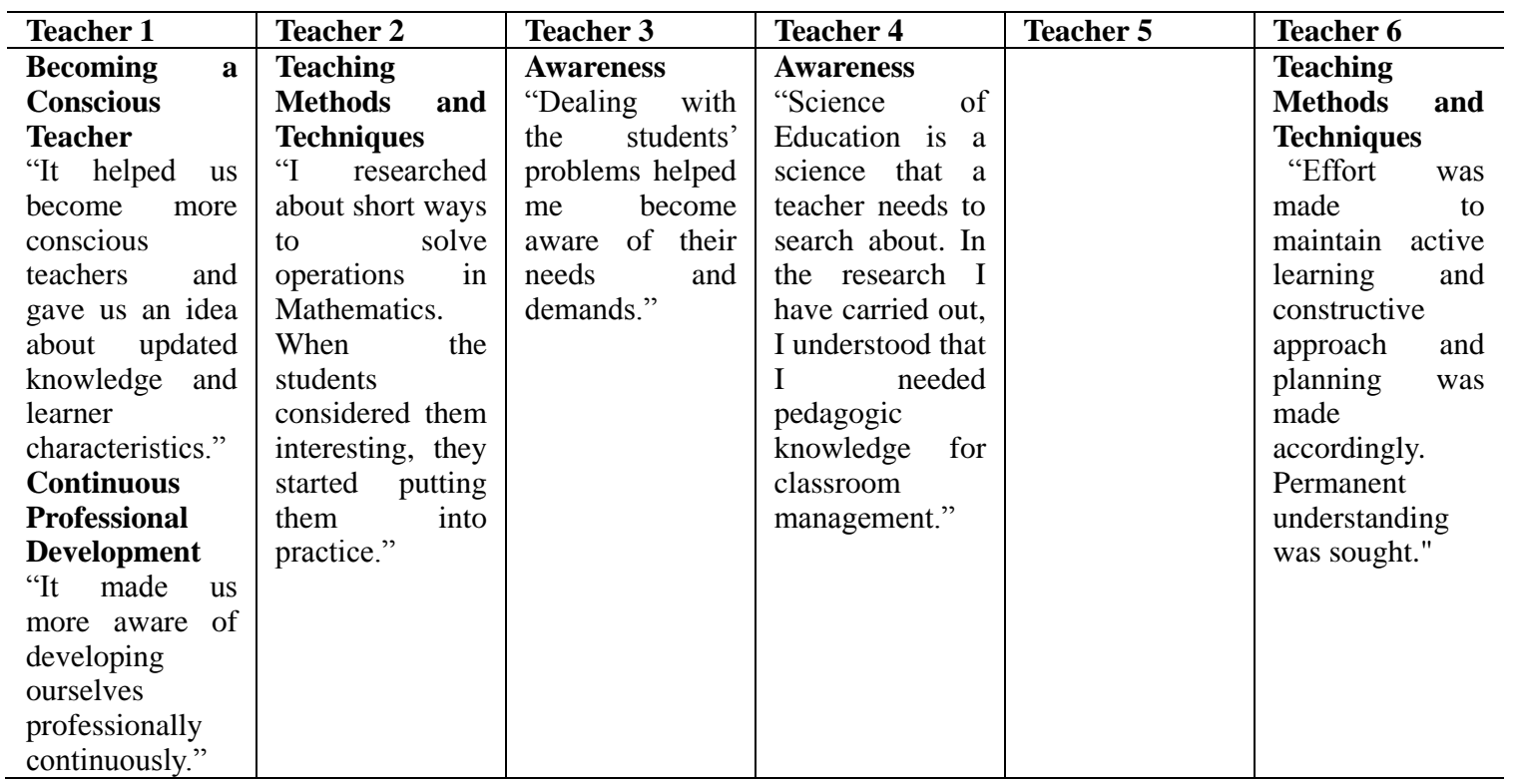

As seen in Table 6, all the opinions of the teachers regarding "General Pedagogical Knowledge" are positive from the point of view of Action Research. The opinions could be gathered under the themes "becoming a conscious teacher, continuous professional development, teaching methods and techniques and awarenss". It was expressed that they put 
activities that make the students more active in the lessons. Then, the teachers stated that they gained awareness of professional development, dealing with the students' problems and classroom management.

The results regarding the second sub-dimension named "School Context" are provided in Table 7 below:

As seen in Table 7, all the opinions of the teachers regarding "School Context" are positive. The opinions could be gathered under the themes "problem solving, school problems, classroom management and material usage". Firstly, it is seen that Action Research was useful for them to find out solutions to their problems and formed a ground for the teachers for common problem solving. Then, classroom management seems to be one of the most serious problems and the lessons were interrupted. Yet, the usage of interesting visuals or materials appears to have made the lessons more interesting after the teachers' action researches.

Table 7. Effect of Action Research on Professional Development in terms of "School Context"

\begin{tabular}{|c|c|c|c|c|c|}
\hline Teacher 1 & Teacher 2 & Teacher 3 & Teacher 4 & Teacher 5 & Teacher 6 \\
\hline $\begin{array}{l}\text { Problem } \\
\text { Solving } \\
\text { "It helped us } \\
\text { put forward } \\
\text { solutions for the } \\
\text { problems in the } \\
\text { school context. } \\
\text { Also, it was } \\
\text { useful for us } \\
\text { create solutions } \\
\text { for the same } \\
\text { school's basic } \\
\text { problems as all } \\
\text { the participants } \\
\text { in the training } \\
\text { worked for the } \\
\text { same school. } \\
\text { Besides, the fact } \\
\text { that almost all } \\
\text { teachers } \\
\text { experience the } \\
\text { same problems } \\
\text { helped us find } \\
\text { out common } \\
\text { and more } \\
\text { radical solutions } \\
\text { directed at these } \\
\text { problems." }\end{array}$ & $\begin{array}{l}\text { School } \\
\text { Problems } \\
\text { "Our school } \\
\text { context is } \\
\text { terrible. While } \\
\text { trying to } \\
\text { manage the } \\
\text { classroom, we } \\
\text { are trying to } \\
\text { struggle against } \\
\text { the negative } \\
\text { outside effects. } \\
\text { While having } \\
\text { our lessons, a } \\
\text { few students } \\
\text { may bust the } \\
\text { school and } \\
\text { disrupt the } \\
\text { lesson. Or, the } \\
\text { students may } \\
\text { not attend the } \\
\text { lesson and, } \\
\text { instead, } \\
\text { interrupt the } \\
\text { lesson to ask for } \\
\text { a sweeper or } \\
\text { something } \\
\text { else." }\end{array}$ & $\begin{array}{l}\text { Classroom } \\
\text { Manage ment } \\
\text { "We have a } \\
\text { more effective } \\
\text { lesson when the } \\
\text { classroom is } \\
\text { managed well." }\end{array}$ & $\begin{array}{l}\text { Problem } \\
\text { Solving } \\
\text { "I realized that } \\
\text { I could } \\
\text { implement a } \\
\text { solution that has } \\
\text { worked in } \\
\text { another } \\
\text { classroom for a } \\
\text { similar } \\
\text { problem." }\end{array}$ & $\begin{array}{l}\text { Research Not } \\
\text { Solved } \\
\text { "I haven't been } \\
\text { able to get a } \\
\text { definite solution } \\
\text { at the end of my } \\
\text { research so far. } \\
\text { However, it } \\
\text { could result in } \\
\text { success with } \\
\text { more effort and } \\
\text { time." }\end{array}$ & $\begin{array}{l}\text { Material Usage } \\
\text { "Our school } \\
\text { context is where } \\
\text { the number of } \\
\text { students with } \\
\text { lack of attention } \\
\text { and suffering } \\
\text { from dyslexia. } \\
\text { That the usage } \\
\text { of materials that } \\
\text { drew the } \\
\text { attention of the } \\
\text { students and } \\
\text { exhibiting them } \\
\text { inside the } \\
\text { school made } \\
\text { learning more } \\
\text { enjoyable." }\end{array}$ \\
\hline
\end{tabular}

As seen in Table 8, all the opinions of the teachers regarding "Getting to Know Oneself" are positive from the point of view of Action Research. The opinions could be gathered under the themes "professional development, scientific process skills, personal development, teaching methods and techniques, problem solving and continuous development". It is seen that the teachers put great emphasis on the effect of Action Research in terms of professional, personal and continuous development. As seen in some other sub-dimensions, it helped the teachers about teaching methods and techniques. Finally, it was useful for the teachers to make a self-criticism and assessment.

The results regarding the second sub-dimension named "Getting to Know Oneself" are provided in Table 8 below: 
Table 8. Effect of Action Research on Professional Development in terms of "Getting to Know Oneself"

\begin{tabular}{|c|c|c|c|c|c|}
\hline Teacher 1 & Teacher 2 & Teacher 3 & Teacher 4 & Teacher 5 & Teacher 6 \\
\hline $\begin{array}{l}\text { Professional } \\
\text { Development } \\
\text { "The training } \\
\text { we have had } \\
\text { contributed to } \\
\text { us in } \\
\text { professional } \\
\text { terms. A teacher } \\
\text { developing } \\
\text { himself/herself } \\
\text { continuously } \\
\text { will want to } \\
\text { keep up with } \\
\text { the changes in } \\
\text { the daily life as } \\
\text { well." } \\
\text { Scientific } \\
\text { Process Skills } \\
\text { "Making use of } \\
\text { scientific } \\
\text { methods will } \\
\text { help th } \\
\text { teachers gain } \\
\text { scientific } \\
\text { process skills, } \\
\text { which will help } \\
\text { us identify and } \\
\text { observe people } \\
\text { and events } \\
\text { around us in a } \\
\text { more objective } \\
\text { way." } \\
\text { Personal } \\
\text { Development } \\
\text { "The training } \\
\text { we teacher } \\
\text { contributed to } \\
\text { us in terms of } \\
\text { professional } \\
\text { development." } \\
\text { Continuous } \\
\text { Development } \\
\text { "A te } \\
\text { developing } \\
\text { himself/herself } \\
\text { continuously } \\
\text { will want to } \\
\text { keep up with } \\
\text { the changes in } \\
\text { the daily life as } \\
\text { well." }\end{array}$ & $\begin{array}{l}\text { Teaching } \\
\text { Methods and } \\
\text { Techniques } \\
\text { "It helped us } \\
\text { realize how to } \\
\text { teach better } \\
\text { using different } \\
\text { methods." } \\
\text { Self-Assessmen } \\
\text { t } \\
\text { "... our school } \\
\text { context and } \\
\text { student profiles } \\
\text { are terrible. I } \\
\text { think I cannot } \\
\text { improve myself } \\
\text { enough in such } \\
\text { an atmosphere." }\end{array}$ & $\begin{array}{l}\text { Problem } \\
\text { Solving } \\
\text { "This research } \\
\text { helped me gain } \\
\text { problem solving } \\
\text { and managing } \\
\text { skills." }\end{array}$ & $\begin{array}{l}\text { Continuous } \\
\text { Development } \\
\text { "... I have } \\
\text { learned that I } \\
\text { need to improve } \\
\text { myself } \\
\text { continuously, } \\
\text { become more } \\
\text { patient and } \\
\text { flexible and } \\
\text { show more } \\
\text { emphaty." } \\
\text { Self-Assessmen } \\
\text { t "This research, } \\
\text { first of all, } \\
\text { helped me make } \\
\text { self-criticism, } \\
\text { notice my } \\
\text { mistakes and } \\
\text { know myself } \\
\text { better." }\end{array}$ & $\begin{array}{l}\text { Self-Assessmen } \\
\text { t } \\
\text { "It has taught } \\
\text { me see myself } \\
\text { in a realistic } \\
\text { way and make a } \\
\text { true assessment } \\
\text { as a result." }\end{array}$ & $\begin{array}{l}\text { Teaching } \\
\text { Methods and } \\
\text { Techniques } \\
\text { "It was } \\
\text { particularly } \\
\text { influential as it } \\
\text { helped us see } \\
\text { our weaknesses } \\
\text { in terms of } \\
\text { teaching } \\
\text { methods and } \\
\text { techniques and } \\
\text { learn how to } \\
\text { improve } \\
\text { ourselves." }\end{array}$ \\
\hline
\end{tabular}

\section{Discussion}

Reeves (2010) expresses that teachers should be provided with different knowledge and skills from those they had in the past if they are expected to enhance their professional practices and decision making (as cited in Hughes, 2016). Teachers involved in Action Research are encouraged to be reflective and analyze their practices to evaluate how strong their pedagogies are to improve student progress (Hughes, 2016). Based on the findings of the research, it could be stated that Action Research is useful for the teachers in several aspects of their professional and personal development. To begin with, as stated in the "Field of Knowledge" sub-dimension, it helped the teachers to make positive sharing, do common plans, offer an opportunity to make self-criticism, improve communication with students and increase their level of awareness. Also, Action Research is seen to increase teachers' knowledge, ensure more active involvement of the students in the lessons and have positive impact upon students as mentioned in the "Gaining Knowledge Regarding Learners", "General Pedagogical Knowledge" and "Teaching Methodologies" sub-dimensions. Similarly, Feldman 
(1996:20-27) found that PTARG (Physics Teachers Action Research Group) produced and shared knowledge in his study. Next, he commented that teachers try new methods in their lessons and enhanced the lessons. The fact that the teachers share and criticize their experiences during their action research results in the growth of their knowledge. Likewise, the teachers had a chance to study together in their Collaborative Action Research (CAR), their understanding of the basic concepts got better, had a chance to reflect upon the activities, realized that they could grow professionally, and helped to notice the importance of working, studying, reflecting and making researches with the other teachers because it permitted them to uncover the significance of sharing their classroom activities and knowledge with their colleagues to keep developing professionally. (Garces and Granada, 2015)

Then, it is said to assist instructs about methodology, learner strategies and classroom materials (Johnson, 1992; McKay, 2009; as cited in Sakirgil, 2014). Sakirgil (2014) concludes in his study that being involved in an action research helps teachers get more conscious of their strong and weak sides as teachers. They are said to know their classes, communicate with the students better and minimize the problems in the classroom. Moreover, Brown (2002) states that the systematic structure of Action Research enables teachers to change their educational methodologies.

Furthermore, as mentioned in the "Curriculum", "General Pedagogical Knowledge", and "School Context" sub-dimensions, it is apparent that teachers improve their problem solving skills using Action Research. In line with that, Bentz and Shapiro (1998) discussed that early studies focused on transforming people's or organizations' behaviours more than Action Research's role as a means of participant problem solving (as cited in Coats, 2005).

Next, Action Research could be said to help teachers about material development as well as stated in the "School Context" sub-dimension. Finally, it is seen that Action Research helps teachers make self-assessment and criticism, has positive impact on their professional, personal and continuous development. Similarly, Bissonnette and Caprino (2014) state that teachers become more reflective and intentional in their instruction and cooperate with their colleagues and advocate Action Research as a means of professional development. Then, Nelluru and Kanta (2016) states that Action Research serves for the goal to be reflective professionally because it combines the professional knowledge and wisdom of daily practice.

Also, Borg (2015) states that teacher (action) research is an option for teachers for their professional development to be continuous, cheap and integrated into their studies. He adds that Action Research should not be regarded as the only and right option for the whole teachers, yet when suitable, he claims that he has considerable transformative potential. Moreover, Coats (2005) report that Action Research is useful for teachers' professional development with some quotations of the teachers involved in an action research and stating that their professional development was enhanced using Action Research.

Yigit (2016) mentions that action research has resulted in significant contributions to the teachers such as finding solutions to their problems on their own, acquisition of scientific research process knowledge, differention in methods and techniques, effective classroom management, etc. Yet, he also suggests carrying out researches about whether the teachers keep using Action Research later on.

As a conclusion, it could be stated that Action Research is helpful for the teachers' professional development in several aspects. Therefore, it could be suggested that teachers be encouraged to initiate and be involved in such researches as such to develop themselves professionally and how permanent these Action Research skills are permanent could be studied.

\section{Acknowledgements}

We thank the teachers conducting their own action researches included in this study.

\section{References}

Avalos, B. (2011). Teacher professional development in teaching and teacher education over ten years. Teaching and Teacher Education, 27(1), 10-20. https://doi.org/10.1016/j.tate.2010.08.007

Baxter, P., \& Jack, S. (2008). Qualitative case study methodology: Study design and implementation for novice researchers. The Qualitative Report, 13(4), 544-559.

Bissonnette, J. D., \& Caprino, K. (2015). A look at ineffective and effective professional development: Moving toward action research. Mid-Atlantic Education Review, 2(1), 2328-3610.

Borg, S. (2015). Teacher research for professional development. International Teacher Educator Conference, 21-23.02.2014, Hyderabad, 23-29.

Brown, B. L. (2002). Improving teaching practices through action research. Doctoral Dissertation, Virginia Polytechnic Institute and State University, Virginia, p. i. 
Business Dictionary. http://www.businessdictionary.com/definition/quality.html (29.10.2015).

Coats, M. (2005). Action Research; a guide for associate lecturers. Centre for Outcomes-Based Education. Open University, Milton Keynes, 4

Commission of the European Communities (CEC). (2007). Improving the quality of teacher education. http://www.atee1.org/uploads/EUpolicies/improving_the_quality_of_teacher_education_aug2007.pdf (29.10.2014).

Ekiz, D. (2006). Ogretmen Egitimi ve Ögretimde Yaklasimlar. Nobel Yayincilik, Ankara, p.6

Feldman, A. (1996). Enhancing the practice of physics teachers: Mechanisms for the generation and sharing of knowledge and understanding in collaborative action research. Journal of research in science teaching, 33(5), 513-540. https://doi.org/10.1002/(SICI)1098-2736(199605)33:5<513::AID-TEA4>3.0.CO;2-U

Ferguson, P. (2011). Action research for professional development: Concise advice for new action researchers. http://www.waikato.ac.nz/tdu/pdf/booklets/24_AR.pdf (13.11.2013)

Garcés, C., Yicely, A., \& Martínez, G. L. (2016). The Role of Collaborative Action Research in Teachers' Professional Development. Profile Issues in Teachers' Professional Development, 18(1), 39-54. https://doi.org/10.15446/profile.v18n1.49148

Guskey, T. R. (2002): Professional development and teacher change. Teachers and Teaching: Theory and Practice, 8(3), 381-391. https://doi.org/10.1080/135406002100000512

Hughes, S. (2016). Joining the Game: Living and Learning as an Action Researcher. The Canadian Journal of Action Research, 17(1), 3-19.

Kim, J. S. (2008). An Examination of EFL Professional Development in Korea: Strategies for Teacher Learning. PhD. Dissertation Paper. University of Wisconsin-Madison, 19-72.

Kuzu, A. (2009). Action research in teacher education and professional development. The Journal of International Social Research, 2(6), 425-433.

Merriam-Webster. http://www.merriam-webster.com/dictionary/quality (29.10.2015)

Mertler, C. A. (2013). Classroom-based action research: revisiting the process as customizable and meaningful professional development for educators. Journal of Pedagogic Development, http://hdl.handle.net/10547/335968(24.05.2015)

Nelluru, I., \& Kanta, P. (2016). Action Research-Focusing on English Language Teaching Practices for Professional Development. International Journal of Engineering Science, 4521.

Sakırgil, L. E. (2014). An Action Research Study on Teacher Development in a University Context. Unpublished Master's Thesis, Mersin, Çağ Üniversitesi, 43-46.

Turk Dil Kurumu (TDK). http://tdk.gov.tr/index.php?option=com_btsvearama=kelimeveguid=TDK.GTS.5631e79a8fcc88.09490727(29.10.2 015)

Villegas-Reimers, E. (2003). Teacher professional development: an international review of the literature. International Institute for Educational Planning. Paris, 7-70.

Wei, R. C., Darling-Hammond, L., \& Adamson, F. (2010). Professional development in the United States: Trends and challenges. Dallas, TX: National Staff Development Council, 1-4.

Word Press. https://oqrmmodel.wordpress.com/2013/02/14/iso-9000s-definition-of-quality/ (14.02.2013).

Yigit, C. (2016). Ogretmenlerin Mesleki Gelisiminde Eylem Arastirrmasinin Kirkpatrick Program Degerlendirme Modeline Gore İncelenmesi. Unpublished Doctoral Dissertation, Gaziantep, Gaziantep University, 216-218.

Yildirim, A., \& Simsek, H. (2006). Sosyal Bilimlerde Nitel Arastırma Yöntemleri. Ankara: Seckin Yayinlari, 276-290.

\section{Copyrights}

Copyright for this article is retained by the author(s), with first publication rights granted to the journal.

This is an open-access article distributed under the terms and conditions of the Creative Commons Attribution license which permits unrestricted use, distribution, and reproduction in any medium, provided the original work is properly cited. 